\title{
Crystal Phase of Fibrous Calcium Phosphates Prepared with Sodium Alginate
}

\author{
Junko HAYASHIZAKI, Seiji BAN, Norihiro ARIMOTO, Norio KATO, \\ Yoshihiro KIMURA ${ }^{1}$ and Jiro HASEGAWA \\ Department of Dental Material Science, School of Dentistry, Aichi-Gakuin University \\ ${ }^{1}$ The Second Department of Oral and Maxillofacial Surgery, School of Dentistry, Aichi-Gakuin University \\ 1-100, Kusumoto-cho, Chikusa-ku, Nagoya 464, Japan
}

Received July 24, 1995/Accepted October 27, 1995

\begin{abstract}
This study investigated the effects of preparation conditions on the crystal phase of the fired fiber prepared with sodium alginate. Hydroxyapatite, $\mathrm{Ca}_{10}\left(\mathrm{PO}_{4}\right)_{6}(\mathrm{OH})_{2}$, hereafter referred to as $\mathrm{HA}$, was only formed in fiber fired at $900^{\circ} \mathrm{C}$ under proper conditions. There was no significant difference in the crystal phase of the fired fibers prepared using different sodium alginate concentrations and syringe nozzle diameter, although fiber diameters were enlarged with increasing in either. No effects of phosphate type on the crystal phase of the fired fiber were found, but the aging time and the rinsing time had great effects. Sodium calcium phosphate, $\mathrm{NaCaPO}_{4}$, and $\mathrm{HA}$ were formed when the aging time was shorter than 5 min. Chlorapatite, $\mathrm{Ca}_{5} \mathrm{Cl}\left(\mathrm{PO}_{4}\right)_{3}$, and $\mathrm{HA}$ were formed when the rinsing time was shorter than $3 \mathrm{sec}$, and $\mathrm{HA}$ was formed when the rinsing time was 5 min to 1 hour, whereas $\beta$-TCP, $\beta$ - $\mathrm{Ca}_{3}\left(\mathrm{PO}_{4}\right)_{2}$, and $\mathrm{HA}$ were formed when the rinsing time exceeded 2 weeks.
\end{abstract}

Key words: Crystal phase, Fiber, Calcium phosphate

\section{INTRODUCTION}

HA is regarded as an effective biomaterial for dental applications and orthopaedic prosthesis as a substitute for bony tissue ${ }^{1-4)}$. HA has a similar microstructure to biological apatite, with excellent biocompatibility, osteoconductivity and nontoxicity ${ }^{5-7}$. Clinical success requires the simultaneous achievement of a stable interface with connective tissue and a match of the mechanical behavior of the implant with the tissue to be replaced ${ }^{8)}$. The bonding of synthetic HA to bone achieved by a direct chemical bond. It has been reported that tissue ingrowth, stimulation of new bone formation, and the biological fixation of the implanted material depend upon the nature of the microstructure configuration ${ }^{9}$. Furthermore, intimate and stable contact with the host bone is the main prerequisite for osteoconduction. However, powdered HA may not provide this stable interfacial contact when implanted into sites where tissue movement occurs ${ }^{10)}$. Therefore, it can be expected that fibrous HA has better fixation in biological tissue than powdered $\mathrm{HA}^{11,12}$. Iwasaki reported that fibrous $\mathrm{HA}$ was prepared using a reaction of ion exchange of sodium alginate ${ }^{13)}$. However, $\mathrm{CaO}$ also formed in the fiber and was removed by chemical etching ${ }^{14)}$. This study attempted to obtain pure fibrous HA and the effects of various conditions on the crystal phase of fibrous calcium phosphates prepared using sodium alginate were investigated. 


\section{MATERIALS AND METHODS}

A starting material was prepared by mixing $5 \mathrm{wt} \%$ sodium alginate and $6.27 \mathrm{mM}$ phosphate, and a spinning solution was prepared by mixing $500 \mathrm{ml}$ of $0.1 \mathrm{M} \mathrm{CaCl}_{2}$ and $500 \mathrm{ml}$ of $0.5 \mathrm{M}$ $\mathrm{Ca}\left(\mathrm{CH}_{3} \mathrm{COO}\right)_{2}$ and adjusted to $\mathrm{pH} 7$ by the addition of $\mathrm{CH}_{3} \mathrm{COOH}$. The starting material was extruded from a syringe into the spinning solution, immediately gelled by an ion exchange reaction of sodium for calcium; the gel fiber was then aged in the spinning solution. Subsequently, the gel fiber was gently rinsed with distilled water to remove the spinning solution covering the fiber, and dried at $37^{\circ} \mathrm{C}$. The fired fiber was prepared by firing the dried fiber at $200-900^{\circ} \mathrm{C}$ for 3 hours.

Table 1 shows the preparation conditions employed in this study. Twenty-four kinds of specimens were prepared by changing six factors; firing temperature, concentration of sodium alginate, diameter of syringe nozzle, type of phosphate, aging time, and rising time. To evaluate the crystal phase, the fired fibers were analyzed using $\mathrm{X}$-ray diffractmetry* and

Table 1 Experimental conditions

\begin{tabular}{|c|c|c|c|c|c|c|c|}
\hline Condition & No. & $\begin{array}{l}\text { Firing temp. } \\
\left({ }^{\circ} \mathrm{C}\right)\end{array}$ & $\begin{array}{c}\text { Sodium } \\
\text { alginate(wt\%) }\end{array}$ & $\begin{array}{c}\text { Nozzle } \\
(\mathrm{mm})\end{array}$ & Phosphate & $\begin{array}{l}\text { Aging } \\
\text { time }\end{array}$ & $\begin{array}{l}\text { Rinsing } \\
\text { time }\end{array}$ \\
\hline \multirow{5}{*}{$\begin{array}{c}\text { Firing } \\
\text { temperature }\end{array}$} & 1 & $*$ & \multirow{5}{*}{5.00} & \multirow{5}{*}{1.25} & \multirow{5}{*}{$\mathrm{Na}_{4} \mathrm{P}_{2} \mathrm{O}_{7}$} & \multirow{5}{*}{$1 \mathrm{~h}$} & \multirow{5}{*}{$5 \mathrm{~min}$} \\
\hline & 2 & 200 & & & & & \\
\hline & 3 & 400 & & & & & \\
\hline & 4 & 600 & & & & & \\
\hline & 5 & 900 & & & & & \\
\hline \multirow{3}{*}{$\begin{array}{l}\text { Concentration } \\
\text { of sodium } \\
\text { alginate } \\
\end{array}$} & 6 & \multirow{3}{*}{900} & 5.00 & \multirow{3}{*}{0.40} & \multirow{3}{*}{$\mathrm{Na}_{4} \mathrm{P}_{2} \mathrm{O}_{7}$} & \multirow{3}{*}{$1 \mathrm{~h}$} & \multirow{3}{*}{$5 \mathrm{~min}$} \\
\hline & 7 & & 1.25 & & & & \\
\hline & 8 & & 0.625 & & & & \\
\hline \multirow{3}{*}{$\begin{array}{c}\text { Diameter of } \\
\text { syringe } \\
\text { nozzle }\end{array}$} & 9 & \multirow{3}{*}{900} & \multirow{3}{*}{5.00} & 0.40 & \multirow{3}{*}{$\mathrm{Na}_{4} \mathrm{P}_{2} \mathrm{O}_{7}$} & \multirow{3}{*}{$1 \mathrm{~h}$} & \multirow{3}{*}{$5 \mathrm{~min}$} \\
\hline & 10 & & & 0.56 & & & \\
\hline & 11 & & & 1.25 & & & \\
\hline \multirow{3}{*}{$\begin{array}{l}\text { Type of } \\
\text { phosphate }\end{array}$} & 12 & \multirow{3}{*}{900} & \multirow{3}{*}{1.25} & \multirow{3}{*}{0.40} & $\mathrm{Na}_{2} \mathrm{HPO}_{4}$ & \multirow{3}{*}{$1 \mathrm{~h}$} & \multirow{3}{*}{$5 \mathrm{~min}$} \\
\hline & 13 & & & & $\mathrm{Na}_{3} \mathrm{PO}_{4}$ & & \\
\hline & 14 & & & & $\mathrm{Na}_{4} \mathrm{P}_{2} \mathrm{O}_{7}$ & & \\
\hline \multirow{5}{*}{ Aging time } & 15 & \multirow{5}{*}{900} & \multirow{5}{*}{5.00} & \multirow{5}{*}{1.25} & \multirow{5}{*}{$\mathrm{Na}_{4} \mathrm{P}_{2} \mathrm{O}_{7}$} & $0 \mathrm{~min}$ & \multirow{5}{*}{$5 \mathrm{~min}$} \\
\hline & 16 & & & & & $1 \mathrm{~min}$ & \\
\hline & 17 & & & & & $5 \mathrm{~min}$ & \\
\hline & 18 & & & & & $10 \mathrm{~min}$ & \\
\hline & 19 & & & & & $1 \mathrm{~h}$ & \\
\hline \multirow{5}{*}{ Rinsing time } & 20 & \multirow{5}{*}{900} & \multirow{5}{*}{5.00} & & & & $0 \mathrm{~s}$ \\
\hline & 21 & & & & & & $3 \mathrm{~s}$ \\
\hline & 22 & & & 1.25 & $\mathrm{Na}_{4} \mathrm{P}_{2} \mathrm{O}_{7}$ & $1 \mathrm{~h}$ & $5 \mathrm{~min}$ \\
\hline & 23 & & & & & & $1 \mathrm{~h}$ \\
\hline & 24 & & & & & & $2 \mathrm{w}$ \\
\hline
\end{tabular}

* : dry, without firing

* Rotaflex RAD-rC, Rigaku, Tokyo, Japan 


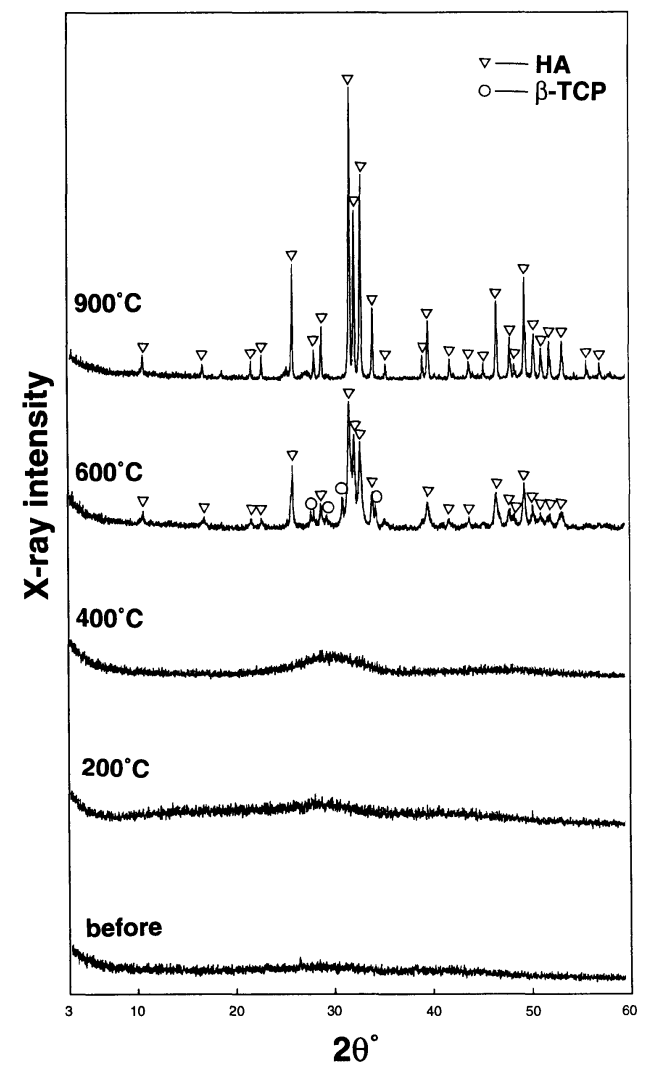

Fig. 1 X-ray diffraction patterns of the fibers before and after firing at 200, 400, 600 and $900^{\circ} \mathrm{C}$.



Fig. 2 FT-IR spectra of the fibers before and after firing at $200,400,600$ and $900^{\circ} \mathrm{C}$.

FT-IR spectroscopy** . The diameters of dried and fired fibers were determined by optical microscopy, and the average diameter and the standard deviation were calculated for each group of 10 specimens. Furthermore, to determine the lattice parameters of HA in the fired fibers after rinsing, 27 specimens prepared using different rinsing times, 3-sec to 1-hour, were analyzed by X-ray diffractmetry. The $a$-axis and $c$-axis dimensions were calculated from the positions of the (300) reflection and the (002) reflection, respectively.

\section{RESULTS}

Fig. 1 shows X-ray diffraction patterns of the fibers before and after firing at various temperatures. The fibers before and after firing at 200 and $400^{\circ} \mathrm{C}$ were amorphous. HA and $\beta$-TCP were observed at $600^{\circ} \mathrm{C}$. HA alone was observed at $900^{\circ} \mathrm{C}$. Fig. 2 shows FT-IR spectra of the fibers before and after firing at various temperatures. The spectra of the

** JIR-Diamond-20, JEOL LTD., Tokyo, Japan 
Table 2 Diameter of dried fibers and fired fibers at $900^{\circ} \mathrm{C}$

\begin{tabular}{cccrc}
\hline \multirow{2}{*}{ Condition } & \multirow{2}{*}{ No. } & Level & \multicolumn{2}{c}{ Diameter $(\mu \mathrm{m})$} \\
\cline { 3 - 5 } & & & Dried fiber & \multicolumn{1}{c}{ Fired fiber } \\
\hline \multirow{2}{*}{ Concentration of } & 6 & $5.00 \mathrm{wt} \%$ & $108.18(16.21)$ & $53.97(9.92)$ \\
sodium alginate & 7 & $1.25 \mathrm{wt} \%$ & $48.65(19.96)$ & $16.67(2.01)$ \\
& 8 & $0.625 \mathrm{wt} \%$ & $18.81(7.27)$ & $10.32(3.01)$ \\
\hline \multirow{2}{*}{ Diameter of } & 9 & $0.40 \mathrm{~mm}$ & $108.18(16.21)$ & $53.97(9.92)$ \\
syringe nozzle & 10 & $0.56 \mathrm{~mm}$ & $133.57(19.40)$ & $67.47(17.73)$ \\
& 11 & $1.25 \mathrm{~mm}$ & $287.14(33.40)$ & $161.82(14.52)$ \\
\hline \multirow{2}{*}{ Type of phosphate } & 12 & $\mathrm{Na}_{2} \mathrm{HPO}_{4}$ & $46.11(16.71)$ & $25.32(6.42)$ \\
& 13 & $\mathrm{Na}_{3} \mathrm{PO}_{4}$ & $43.16(16.13)$ & $22.54(6.39)$ \\
& 14 & $\mathrm{Na}_{4} \mathrm{P}_{2} \mathrm{O}_{7}$ & $48.65(19.96)$ & $24.13(2.60)$ \\
\hline
\end{tabular}

The figures shown are averages (standard deviation).

Vertical lines indicate no significant difference at the level of 0.05 .

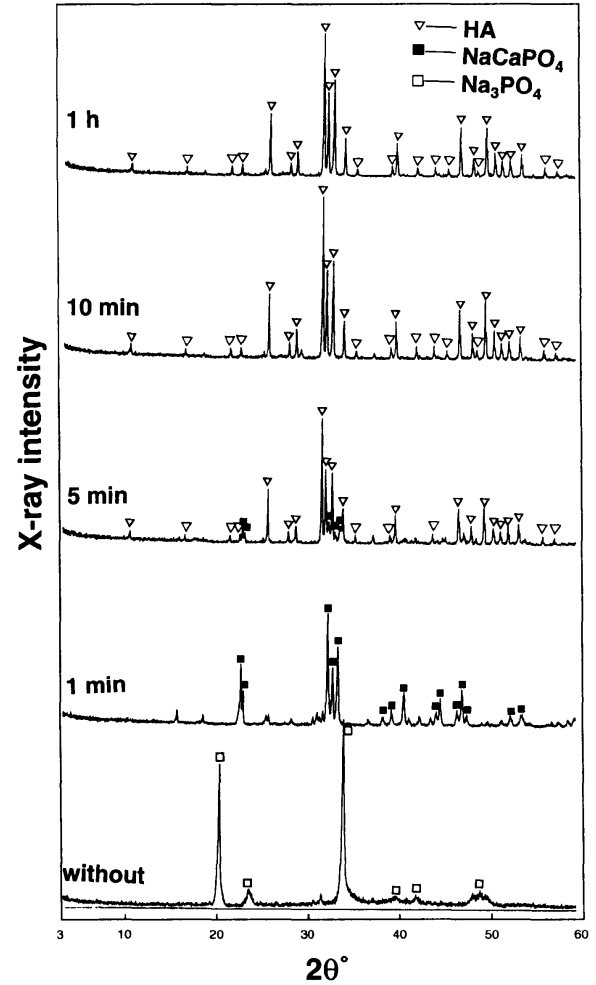

Fig. $3 \mathrm{X}$-ray diffraction patterns of the fired fibers prepared without and with 1 -min, 5-min, 10-min and 1-hour aging.

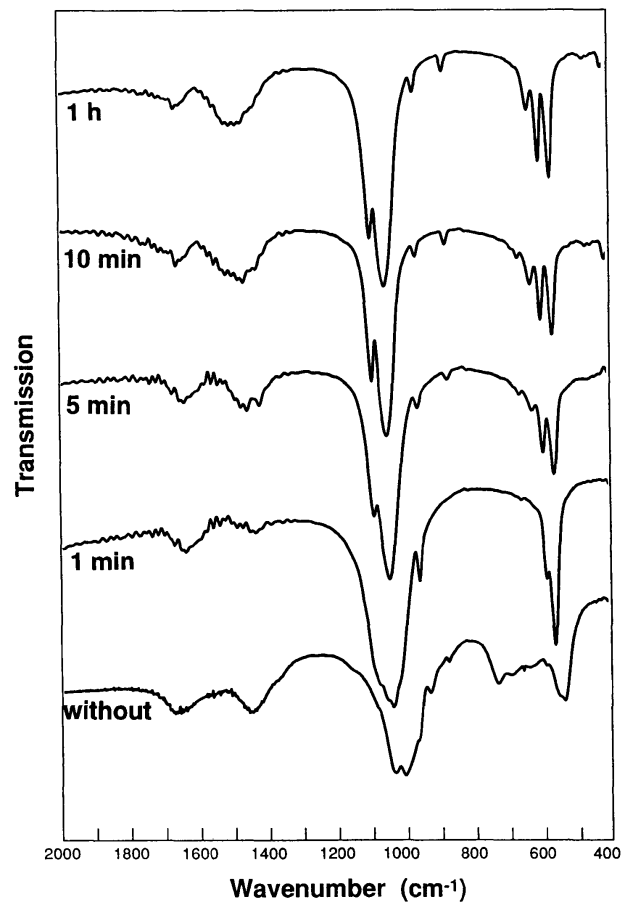

Fig. 4 FT-IR spectra of the fired fibers prepared without and with 1-min, 5-min, $10-\mathrm{min}$ and 1 -hour aging. 


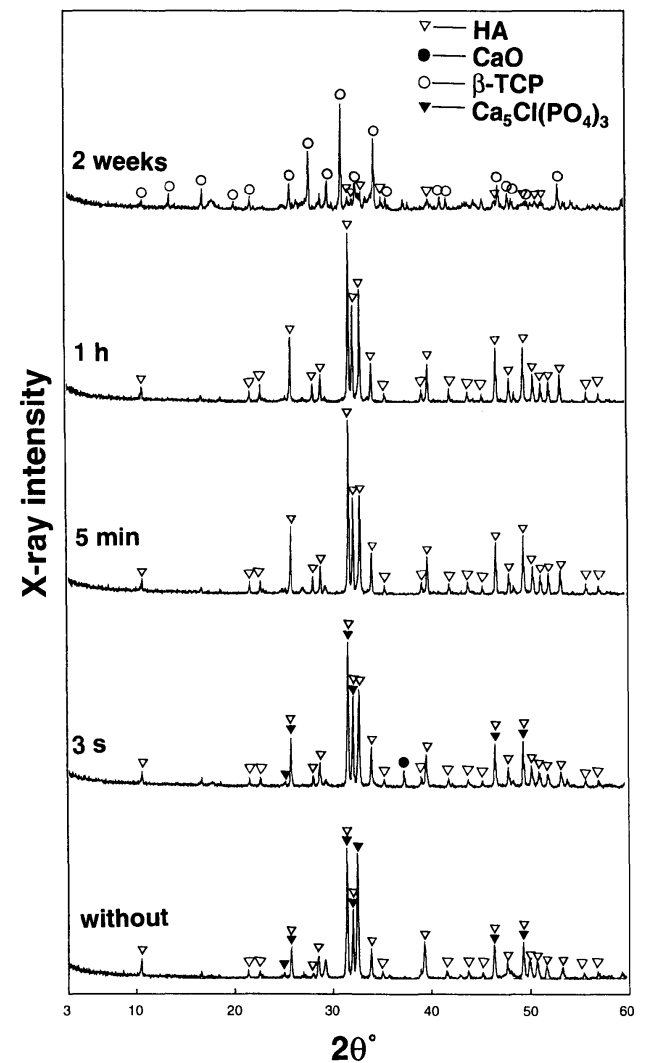

Fig. $5 \quad \mathrm{X}$-ray diffraction patterns of the fired fibers prepared without and with $3-\mathrm{sec}$, 5-min, 1-hour and 2-week rinsing.

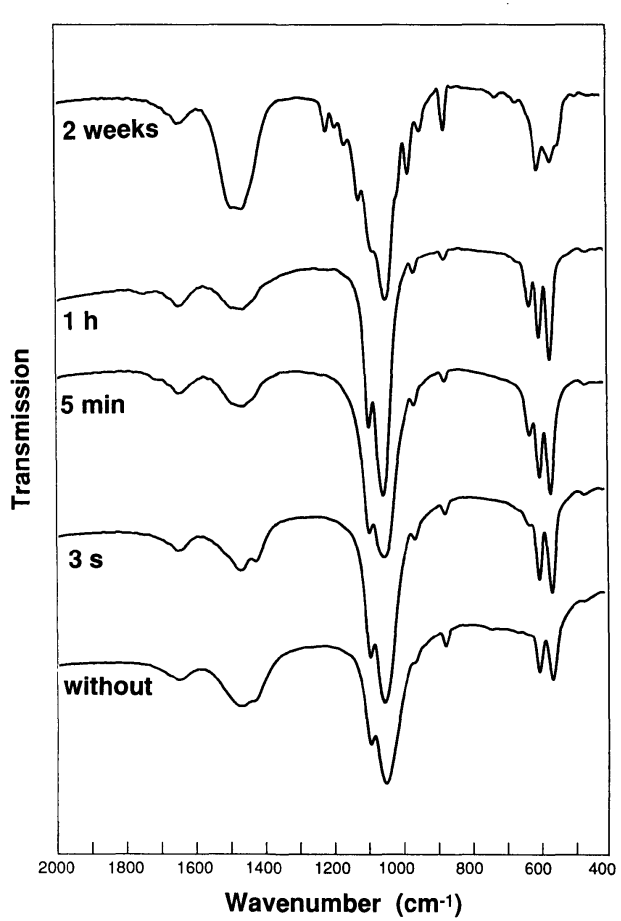

Fig. 6 FT-IR spectra of the fired fibers prepared without and with $3-\mathrm{sec}, 5-\mathrm{min}, 1$ -hour and 2-week rinsing.

fiber before and after firing $200^{\circ} \mathrm{C}$ showed that alginate still remained, because peaks due to alginate were observed around $1620,1420,920$ and $820 \mathrm{~cm}^{-1}$. At $400^{\circ} \mathrm{C}$, the $\mathrm{PO}_{4}$ bands were observed around 1040 and $580 \mathrm{~cm}^{-1}$, indicating the presence of amorphous calcium phosphate. The peak intensities of the $\mathrm{PO}_{4}$ groups increased with increasing firing temperatures and the $\mathrm{PO}_{4}$ bands in the $600-570 \mathrm{~cm}^{-1}$ region were more clearly split at 600 and $900^{\circ} \mathrm{C}$, indicating higher crystallinity. Furthermore, $\mathrm{CO}_{3}$ bands around 1430 and $870 \mathrm{~cm}^{-1}$ were also observed in the spectra of the fibers fired at 400,600 and $900^{\circ} \mathrm{C}$.

Table 2 shows the average diameter of dried and fired fibers of specimens No. 6-14 listed in Table 1. The diameter of the fiber significantly increased with increasing concentrations of sodium alginate and syringe nozzle diameters. However, there was no significant difference in the X-ray diffraction patterns and FT-IR spectra among these specimens. Furthermore, there was no significant difference in the diameter, X-ray diffraction pattern, or FTIR spectra of the fired fibers prepared using three kinds of phosphates. Fig. 3 shows X-ray diffraction patterns of the fired fibers prepared using different aging times in the spinning solution. All the diffraction peaks in the X-ray diffraction pattern of the fiber prepared without aging were identified with sodium phosphate, $\mathrm{Na}_{3} \mathrm{PO}_{4}$. The fiber prepared with 1- 

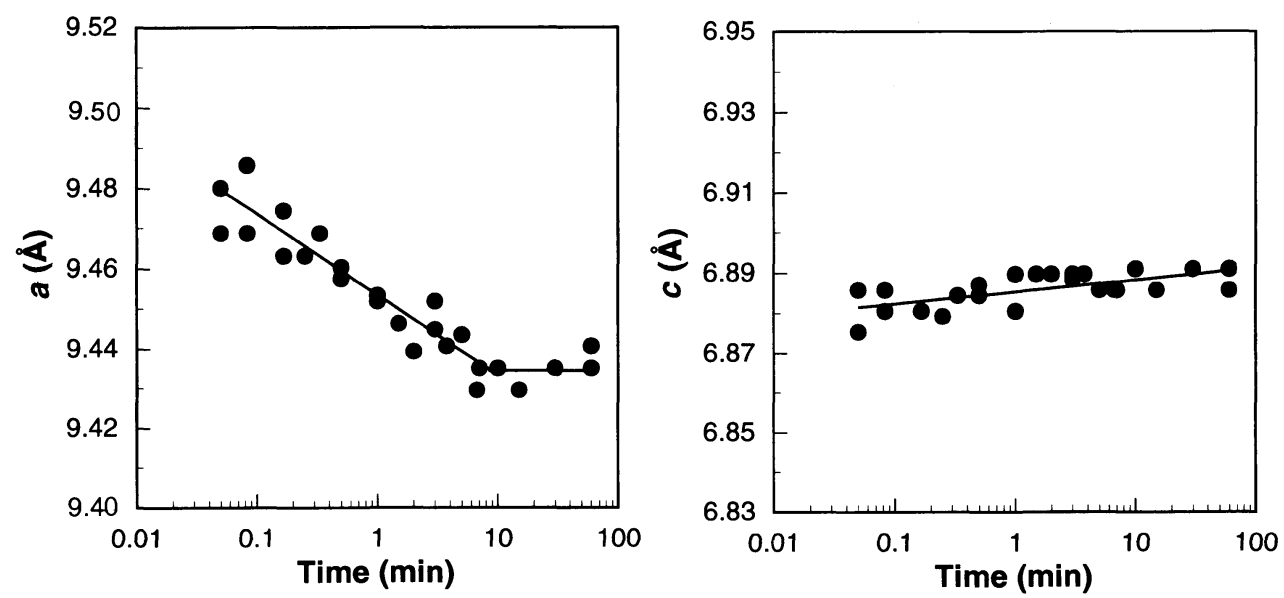

Fig. 7 Lattice parameters of the $a$-axis (left) and $c$-axis (right) of HA in the fired fibers as a function of rinsing time.

min and 5-min aging showed diffraction peaks of hydroxyapataite and/or sodium calcium phosphate. The intensity ratio of $\mathrm{HA}$ to sodium calcium phosphate increased with aging time. After 10-min aging, the fired-fiber showed only diffraction patterns of HA. There was no remarkable difference in the $\mathrm{X}$-ray diffraction patterns from 10-min to 1-hour aging. Fig. 4 shows FT-IR spectra of the fiber prepared with different aging times. The spectra of the fired-fibers prepared with 1-min and 5-min aging had strong $\mathrm{PO}_{4}$ bands around 1100-1010 $\mathrm{cm}^{-1}$ and $600-570 \mathrm{~cm}^{-1}$, indicating the presence of $\mathrm{HA}^{15)}$. After 10-min aging, these absorption bands became strong, indicating high crystallinity. FT-IR spectrum of the fiber prepared without aging showed quite different $\mathrm{PO}_{4}$ absorption peaks from those of the other fibers, as described in $\mathrm{X}$-ray diffraction study (Fig. 3).

Fig. 5 shows X-ray diffraction patterns of the fired fibers prepared using different rinsing times. $\mathrm{X}$-ray diffraction patterns of unrinsed fibers without and those rinsed for 3 sec showed the peaks due to $\mathrm{HA}, \mathrm{CaO}$ and chlorapatite. After 5-min and 1-hour rinsing, the $\mathrm{X}$-ray diffraction patterns indicated the formation of pure HA. In specimens rinsed for 2 weeks, peaks due to $\beta$-TCP were observed in the X-ray diffraction patterns. Fig. 6 shows FT-IR spectra of the fired fibers prepared with various rinsing times. After rinsing for 5 min, strongly $\mathrm{PO}_{4}$ bands were observed around the $1100-1010 \mathrm{~cm}^{-1}$ and $600-570 \mathrm{~cm}^{-1}$ absorption bands, indicating the presence of HA. After rinsing for 2 weeks, absorption bands around 1300 and $540 \mathrm{~cm}^{-1}$ were observed. This suggests that $\beta$-TCP was formed in the mixture with $\mathrm{HA}$ in the fired fiber ${ }^{16)}$.

Fig. 7 shows lattice parameters of the $a$-axis and $c$-axis of HA of the fired fibers prepared with various rinsing times. The lattice parameters of the $a$-axis were in inverse proportion to the logarithm of rinsing time up to about $10 \mathrm{~min}$, whereas those of the $c$-axis are in the range from 6.875 to $6.890 \AA$. After rinsing for $10 \mathrm{~min}$, the parameters of $a$-axis became a constant $9.43 \AA$.

From these results, the crystal phases of the fired fibers prepared under various conditions are summarized in Table 3. 
Table 3 Crystal phases of fired fibers

\begin{tabular}{|c|c|c|c|}
\hline Condition & No. & Level & Crystal phase \\
\hline \multirow{5}{*}{$\begin{array}{l}\text { Firing } \\
\text { temperature }\end{array}$} & 1 & * & amorphous alginate containing calcium and phosphate \\
\hline & 2 & $200^{\circ} \mathrm{C}$ & amorphous alginate containing calcium and phosphate \\
\hline & 3 & $400^{\circ} \mathrm{C}$ & amorphous calcium phosphate \\
\hline & 4 & $600^{\circ} \mathrm{C}$ & $\beta-\mathrm{TCP}, \mathrm{HA}$ \\
\hline & 5 & $900^{\circ} \mathrm{C}$ & HA \\
\hline \multirow{3}{*}{$\begin{array}{l}\text { Concentration of } \\
\text { sodium alginate }\end{array}$} & 6 & $5.00 \mathrm{wt} \%$ & $\mathrm{HA}$ \\
\hline & 7 & $1.25 w t \%$ & $\mathrm{HA}$ \\
\hline & 8 & $0.625 \mathrm{wt} \%$ & $\mathrm{HA}$ \\
\hline \multirow{3}{*}{$\begin{array}{c}\text { Diameter of } \\
\text { syringe nozzle }\end{array}$} & 9 & $0.40 \mathrm{~mm}$ & HA \\
\hline & 10 & $0.56 \mathrm{~mm}$ & $\mathrm{HA}$ \\
\hline & 11 & $1.25 \mathrm{~mm}$ & HA \\
\hline \multirow{3}{*}{$\begin{array}{l}\text { Type of } \\
\text { phosphate }\end{array}$} & 12 & $\mathrm{Na}_{2} \mathrm{HPO}_{4}$ & HA \\
\hline & 13 & $\mathrm{Na}_{3} \mathrm{PO}_{4}$ & $\mathrm{HA}$ \\
\hline & 14 & $\mathrm{Na}_{4} \mathrm{P}_{2} \mathrm{O}_{7}$ & $\mathrm{HA}$ \\
\hline \multirow{5}{*}{ Aging time } & 15 & $0 \mathrm{~min}$ & $\mathrm{Na}_{3} \mathrm{PO}_{4}$ \\
\hline & 16 & $1 \mathrm{~min}$ & $\mathrm{NaCaPO}_{4}$ \\
\hline & 17 & $5 \mathrm{~min}$ & $\mathrm{NaCaPO}_{4}, \mathrm{HA}$ \\
\hline & 18 & $10 \mathrm{~min}$ & $\mathrm{HA}$ \\
\hline & 19 & $1 \mathrm{~h}$ & $\mathrm{HA}$ \\
\hline \multirow{5}{*}{ Rinsing time } & 20 & $0 \mathrm{~s}$ & chlorapatite, HA \\
\hline & 21 & $3 \mathrm{~s}$ & chlorapatite, $\mathrm{HA}, \mathrm{CaO}$ \\
\hline & 22 & $5 \mathrm{~min}$ & $\mathrm{HA}$ \\
\hline & 23 & $1 \mathrm{~h}$ & $\mathrm{HA}$ \\
\hline & 24 & $2 \mathrm{w}$ & $\beta$-ТCP, HA \\
\hline
\end{tabular}

* : dry, without firing

\section{DISCUSSION}

The results of the present study showed no significant difference in the crystal phase of the fired fiber prepared with different concentration of sodium alginate and syringe nozzle sizes, although fiber diameter strongly depended on these factors. It is postulated that the type of phosphate used has no effect on the fiber. One-hour aging was employed in these experiments, Nos. 1-14 and 20-24 listed in Table 1; it seems that 1-hour aging was sufficient for gelation of the starting material by the reaction of ion exchange of sodium for calcium. Our previous study ${ }^{17}$ demonstrated that sodium alginate solution had higher viscosity with increased concentrations of sodium alginate, and its rheological behavior was pseudo-plastic. This implies that the flow rate depends more strongly on the concentration of sodium alginate than shear stress, and that the gellation of the fiber is completed immediately upon leaving the syringe. It seems that the cross linking of the alginate-calcium-phosphate is formed immediately and has strong mutual bonding. As a result, the phosphorous ions hardly release from the gel structure. As shown in Figs. 3 and 4, the aging time in the spinning solution has a great effect on the crystal phase of the fired fiber. This seems to be caused by the persistence of $\mathrm{Na}^{+}$ions in the gel fiber due to the insufficient ion exchange of sodium for calcium during a short aging time. These $\mathrm{Na}^{+}$ions were incorporated in the apatite structure by firing. This suggests that the aging time should be extended at least 10 
min after apparent gelation to allow completion of the ion exchange.

Furthermore, chlorapatite was formed in the fired-fiber with insufficient rinsing time as shown in Fig. 5. LeGeros ${ }^{8}$ reported that the substitution of $\mathrm{Cl}$ for $\mathrm{OH}$ in apatites prepared from aqueous and non-aqueous systems is accompanied by expansion in the $a$-axis and contraction in the $c$-axis dimensions. The lattice parameters of the chlorapatite were $a-$ axis $=9.647$ and $c$-axis $=6.771$, and the lattice parameters of HA were $a$-axis $=9.442$ and $c$-axis $=6.882$, due to the differences in the ionic radii of the substituents. In the present study, the substitution of $\mathrm{OH}$ for $\mathrm{Cl}$ in apatite was also observed by a contraction in the $a-$ axis and a slight expansion in the $c$-axis dimensions. It seems that the surfaces of gel fibers were covered with the spinning solution containing $\mathrm{Cl}^{-}$and $\mathrm{Ca}^{2+}$ ions even after complete gelation in the solution, and the needless spinning solution covering the fiber was gradually removed by rinsing. Thus, insufficient rinsing time resulted in the formation of HA and chlorapatite in the fired-fiber. This suggests that the gel fiber should be thoroughly rinsed, although excess rinsing time resulted in the formation of HA and $\beta$-TCP. This seems to be caused by a decrease in the $\mathrm{Ca} / \mathrm{P}$ ratio of the gel fiber due to the release of $\mathrm{Ca}^{2+}$ ions from the gel structure during prolonged soaking.

From these results, it is concluded that fibrous HA with a high degree of purity can be obtained by properly controlling of these factors during preparation.

\section{CONCLUSION}

Fibrous calcium phosphates were prepared using an ion exchange reaction of sodium for calcium. Although the diameter of the fiber increased with both the sodium alginate concentration and the syringe nozzle diameter, there was no significant difference in the crystal phase of the fibers prepared by varying these factors. No effect of phosphate type on the crystal phase of the fired fiber was observed, but the aging time and the rinsing time had great effects. The fired fiber contained sodium phosphate and/or sodium calcium phosphate when the aging time was insufficient, whereas the fired fiber consisted of HA and chlorapatite when the rinsing time was insufficient. These results indicate that pure fibrous HA can be obtained by properly controlling these factors.

\section{REFERENCES}

1) Hench, L. L. : Bioceramics: From concept to clinic, J Am Ceram Soc 74 (7) : 1487-1510, 1991.

2) Froum, S. J., Kushner, L., Scopp, I. W. and Stahl, S. S. : Human clinical and histologic responses to durapatite implants in intraosseous lesions, J Periodontol 53 (12) : 719-725, 1982.

3) Moriwaki, Y.: Some application of hydroxyapatite ceramics as a bio-material (1), The Nippon Dent Rev 512: 187-197, 1985. (in Japanese)

4) Nery, E. B., Lynch, K. L., Hirthe, W. M. and Mueller, K. H. : Bioceramic implants in surgically produced infrabony defects, J Periodontol 46 (6) : 328-347, 1975.

5) Ducheyne, P.: Bioceramics: Material characteristics versus in vitro behavior, J Biomed Mater Res 21 (A2) : 219-236, 1987.

6) Denissen, H. W., de Groot, K., Makkes, P. Ch., van den Hooff, A. and Klopper, P. J. : Tissue response to dense apatite implants in rats, J Biomed Mater Res 14:713-721, 1980.

7) van der Meulen, J. and Koerten, H. K.: Inflammatory response and degradation of three types of 
calcium phosphate ceramic in a non-osseous environment, $J$ Biomed Mater Res 28: 1455-1463, 1994.

8) LeGeros, R. Z. : Apatites in biological systems, Prog Crystal Growth Charact 4: 1-45, 1981.

9) Salyer, K., Holmes, R. and Johns, D.: Replamineform porous hydroxyapatite as bone substitute in craniofacial osseous reconstruction, J Dent Res 56B : 173, 1977.

10) Ylinen, P. : Filling of bone defects with porous hydroxyapatite reinforced with polylactide or polyglycolide fibres, J Mat Sci Mater Med 5 : 522-528, 1994.

11) Kasuga, T., Ichino, A. and Abe, Y.: Preparation of calcium phosphate fibers for applications to biomedical fields, J Ceram Soc Japan 100 (8) : 1088-1089, 1992.

12) Hayashizaki, J., Ban, S., Arimoto, N., Kataoka, H., Miyazawa, K. and Hasegawa, J. : Preparation of hydroxyapatite fiber by using alginate and its application to bioceramics, Bioceramics 7 (Proc. 7th Intern. Symp. Ceramics in Medicine) : 41-46, 1994.

13) Iwasaki, H. : Fibrous hydroxyapatite, Ceramics $24: 295-299$, 1989. (in Japanese)

14) Iwasaki, H. and Kaneko, Y.: Preparation of fibrous hydroxyapatite by use of sodium alginate, Materials 37 (412): 60-64, 1988. (in Japanese)

15) Sauer, G. R. and Wuthier, R. E.: Fourier transform infrared characterization of mineral phases formed during induction of mineralization by collagenase-released matrix vesicles in vitro, $J$ Biol Chem 263 (27) : 13718-13724, 1988.

16) Fowler, B. O.: Infra-red spectra of hydroxyapatite, octacalcium phosphate and pyrolysed octacalcium phosphate, Arch Oral Biol 11: 477-492, 1966.

17) Hayashizaki, J., Ban, S. and Hasegawa, J.: Preparation of hydroxyapatite fibers by gelation of sodium alginate. Part 1. Relation between the preparation conditions and the products, $J J$ Dent Mater, 12 (Special Issue 22) : 46-47, 1993. (in Japanese) 
アルギン酸ナトリウムを用いて合成した繊維状リン酸カルシウム塩の結晶相 林崎順子, 伴 清治, 有本憲弘, 加藤教授

木村嘉宏 ${ }^{1}$, 長谷川二郎

愛知学院大学歯学部歯科理工学講座

1愛知学院大学歯学部口腔外科学第 2 講座

リン酸塩を混合したアルギン酸ナトリウム水溶液を， ズルを装着したシリンジを用いて，塩化カルシウムと酢 酸カルシウムを混合し酢酸で $\mathrm{pH} 7$ に調整した紡系液中 に吐出し, イオン交換させ,ケ゚ル状繊維を合成した。乾 燥後, 大気中焼成し繊維状リン酸カルシウム塩を得た。 焼成温度の上昇に伴い, 繊維状リン酸カルシウム塩の結 晶性は増加し, $900^{\circ} \mathrm{C}$ 焼成時にハイドロキシアパタイト $\left(\mathrm{Ca}_{10}\left(\mathrm{PO}_{4}\right)_{6}(\mathrm{OH})_{2}\right.$, 以下 $\mathrm{HA}$ と略す $)$ の単一結晶相を
呈した。ゲル状繊維の紡系液中での熟成時間が 5 分以下 の時, 焼成繊維は $\mathrm{HA}$ 及び $\mathrm{NaCaPO}_{4}$ の混合結晶相で あった. また, 焼成瀻維は熟成後の蒸留水による水洗時 間が 3 秒以下の時, $\mathrm{HA}$, クロルアパタイト $\left(\mathrm{Ca}_{5} \mathrm{Cl}\right.$ $\left.\left(\mathrm{PO}_{4}\right)_{3}\right)$ 及び酸化カルシウムの混合結晶相であり，5分 〜 1 時間では HA の単一結晶相であった. しかし, 水洗 時間が 2 週間を越えると, $\mathrm{HA}$ と $\beta-\mathrm{Ca}_{3}\left(\mathrm{PO}_{4}\right)_{2}$ の混合結 晶相を呈した。

\section{臼歯部用光重合型コンポジットレジンの疲労強度}

山本 仁, 高橋英和 ${ }^{1}$

東京医科歯科大学歯学部口腔総合診断学講座

${ }^{1}$ 東京医科歯科大学歯学部歯科理工学第 1 講座

近年, 歯科材料における疲労特性の重要性が指摘され ている. そこで本研究では水中保管した 2 種類のコンポ ジットレジンの疲労特性について検討した。試験には Hybrid type と MFR type の 2 種類のコンポジットレ ジンを用い, ダンベル型の試片を作製し， $37^{\circ} \mathrm{C}$ 水中に 24 時間, 1 力月間, 3 力月間, 6 力月間, 12 力月間保管し てから疲労試験と引張試験を行った. 疲労試験ではステ アケース法を用いて $10^{5}$ 回における疲労強度を求めた。
24 時間後の疲労強度は, Hybrid type て $54.7 \mathrm{MPa,}$ MFR type で $28.1 \mathrm{MPa}$ であり, ともに経時的に減小傾 向がみられた。一方, 直接引張強さは Hybrid typeで $77.0 \mathrm{MPa}$, MFR type で53.5 MPa であり, Hybrid type では水中保管期間にかかわらず変化がみられな かったが, MFR type では経時的に小さくなる傾向が認 められた.

\section{機能性タンパク質薄膜によるインプラント用金属表面の化学修飾}

（第 1 報）修飾表面の分子構造と生体活性

$$
\text { 遠藤一彦 }
$$

北海道医療大学歯学部歯科理工学講座

インプラント用金属に生体活性を付与するために，金 属表面を機能性タンパク質で化学修飾する方法を検討し た. 今回はシッフ塩基結合法を用い, NiTi 合金表面に接 着性タンパク質として知られる血墏フィブロネクチン
（pFN）を固定化し，各処理段階における表面構造をX 線光電子分析装置で調ぺた. さらに, 固定化した $\mathrm{pFN}$ を フルオレサミンを用いた蛍光法により定量した. その結 果, $\mathrm{pFN}$ は合金表面に結合したシランカップリング剤に 